\title{
Effects of GnRH administration on ovulation and fertility in ewes subjected to estrous synchronization
}

\author{
Amanda dos Santos Cavalcanti ${ }^{1}$ Felipe Zandonadi Brandão ${ }^{1}$, Luiz Altamiro Garcia \\ Nogueira $^{1}$, Jeferson Ferreira da Fonseca ${ }^{2}$
}

\author{
1 Programa de Pós-Graduação em Medicina Veterinária - Faculdade de Veterinária, Universidade Federal Fluminense. Rua Vital Brasil \\ Filho, 64, Niterói, RJ, Brasil, 24230-340. \\ 2 Embrapa Caprinos e Ovinos, Sobral, CE, Brasil.
}

\begin{abstract}
The objective of this study was to verify the effects of GnRH on ovulation and pregnancy of ewes subjected to a short-term synchronization of estrus. Santa Inês and crossbred Santa Inês/Dorper ewes received $60 \mathrm{mg}$ MAP sponges during 6 days plus $300 \mathrm{IU}$ eCG and $30 \mu \mathrm{g}$ d-cloprostenol $24 \mathrm{~h}$ prior to sponge withdrawal (SW). Ewes were assigned to receive $0.9 \%$ $\mathrm{NaCl}$ solution $\left(\mathrm{T}_{\text {control }} ; \mathrm{n}=32\right.$ ) or $25 \mu \mathrm{g} \mathrm{GnRH}$ (licerelin, $\mathrm{T}_{\mathrm{GnRH}} ; \mathrm{n}=34$ ) 24 hours after $\mathrm{SW}$. Each group was assigned to intrauterine insemination by laparoscopy $(n=25)$ or to natural mating $(n=41)$. Artificial insemination was performed with a single dose of fresh semen. For controlled mating, females were exposed to males 12, 24, 36 and 48 hours after SW. Ten females per treatment were subjected to transrectal ultrasound examination at 12-hour intervals (SW to 60 hours after). Estrous response (100.0\% vs 95.2\%), interval from SW to estrus (32.9 \pm 7.4 vs $29.8 \pm 6.9$ hours), estrous length $(37.4 \pm 9.0$ vs $31.5 \pm 10.4$ hours), pregnancy rates $(57.0 \%$ vs $41.0 \%)$, ovulation rate $(100.0 \%$ vs $90.0 \%)$, number of ovulations/ewe $(1.1 \pm 0.3$ vs $1.2 \pm 0.4)$, maximum follicular diameter $(6.4 \pm 0.7$ vs $6.1 \pm 0.6 \mathrm{~mm})$, interval from $\mathrm{SW}$ to ovulation $(59.1 \pm 3.5$ vs $58.4 \pm 3.5$ hours $)$ did not differ between $\mathrm{T}_{\text {control }}$ and $\mathrm{T}_{\mathrm{GnRH}}$, respectively. Administration of GnRH 24 hours after $\mathrm{SW}$ does not improve ovulation or pregnancy rate in estrous synchronization in ewes.
\end{abstract}

Key Words: artificial insemination, intravaginal progesterone insert, ovulation, pregnancy rate, sheep

\section{Introduction}

The use of reproductive biotechnologies associated to induction of a synchronized estrus is a valuable tool that favors productivity, offers homogeneous groups of animals and consequently allows the constancy of products offered irrespective to season. Ovarian response of sheep to estrous synchronization varies according to the type of intravaginal device, kind of progestagen, nutritional status, presence of stress, environmental aspects, male effect (Hill et al., 1997; Amarantidis et al., 2006; Kleemann et al., 2006) and breed (Boscos et al., 2002), although Donovan et al. (2004) found no breed effect.

The Gonadotropin-releasing hormone $(\mathrm{GnRH})$ is the key neuro-peptide controlling reproductive function in all vertebrate species. In females of spontaneously ovulating species, including sheep, ovarian steroids secreted by maturing ovarian follicles control a pulsatile pattern of GnRH release from the hypothalamus that, in turn, stimulates a preovulat ory secretion of luteinizing hormone (LH) by the anterior pituitary gland (Bakker \& Baum, 2000). The GnRH treatment induces an LH peak within 1-4 h of treatment and reduces the period over which ovulation occurs (Eppleston et al., 1991).

Many authors have successfully used GnRH treatment in combination with progestagens, gonadotropins and prostaglandin (Husein \& Kridli, 2003; Reyna et al., 2007; Rubianes et al., 2007; Beilby et al., 2009) or prostaglandin only (Murdoch \& Van Kirk, 1998; Deligiannis et al., 2005); and it is well known that all preovulatory events and ovulation can be induced in seasonally anovular ewes if they are treated with multiple injections of GnRH. Besides, it has been demonstrated that exogenous GnRH treatment immediately after artificial insemination increases the multiple birth rate in synchronized ewes (Türk et al., 2008).

Fertility was related positively to concentrations of progesterone during exogenous treatment (Johnson et al., 1996). A short-term treatment provides exposure to higher average concentrations of progestagen during the treatment period. Such treatments ( 5 to $8 \mathrm{~d}$ ) have been effective in anestrous ewes (Knights et al., 2001). The efficiency in synchronizing oestrus of short progestagen protocol is given by the fact that progestagen prevents new formation of corpora lutea (Martemucci \& D'Alessandro, 1999; 
Wildeus, 2000) and when given with prostaglandins (PG) and gonadotropins, progestagen ensures the luteolysis 5 days later and eCG improves the synchronization.

The objective of this study was to evaluate reproductive parameters and $\mathrm{GnRH}$ influence on ovulation and pregnancy rate in ewes subjected to estrous induction and synchronization.

\section{Material and Methods}

This experiment was conducted in Cachoeiras de Macacu, Rio de Janeiro, southeast Brazil (tropical region), during the summer. The farm is located at $22^{\circ} 27^{\prime} \mathrm{S}, 43^{\circ} 39^{\prime} \mathrm{W}$.

A total of 66 ewes during breeding season were studied, 54 of Santa Inês breed and 12 crossbreed Santa Inês/Dorper ewes. The ewes had been maintained isolated from any ram for at least one month prior to the experiment. Body condition score (BCS, ranging from 1 to 5 ) was evaluated by palpation of the lumbar and sternal region. The mean BCS and weight for all ewes were $3.2 \pm 0.5$ and $41.8 \pm 9.6 \mathrm{~kg}$, respectively. Animals were kept in a semi-intensive system on Brachiaria $s p$ paddocks, and also received concentrate once a day. Water and mineral salt were offered ad libitum. Two Santa Inês and one Dorper rams were used for semen collection and natural mating. The rams (aged between 1.5 and 3 years) were sexually active and tested for fertility, and blocked between treatments.

Ewes were equally divided into two treatment groups: control ( $\mathrm{T}_{\text {Control, }} \mathrm{n}=32,3.2 \pm 0.5$ and $41.5 \pm 10.6 \mathrm{~kg}$ ) and treated $\left(\mathrm{T}_{\mathrm{GnRH}}, \mathrm{n}=34,3.2 \pm 0.5\right.$ and $\left.41.8 \pm 9.6 \mathrm{~kg}\right)$ according to the BCS and weight. Estrus was induced using vaginal sponges impregnated with $60 \mathrm{mg}$ Medroxiprogesterone Acetate (Progespon ${ }^{\circledR}$, Tecnopec, SP, Brazil) for 6 days. A dose of 300 IU eCG i.m. (Novormon $5000^{\circledR}$, Tecnopec, SP, Brazil) and $30 \mu \mathrm{g}$ d-cloprostenol (Prolise ${ }^{\circledR}$, ARSA S.R.L., Buenos Aires, Argentina) via the intra-vulvo-submucosal route was administered $24 \mathrm{~h}$ prior to sponge removal. One day after sponge removal, $\mathrm{T}_{\text {Control }}$ received $1.0 \mathrm{~mL} \mathrm{NaCl}$ $0.9 \%$ solution and $\mathrm{T}_{\mathrm{GnRH}}$ received $25 \mu \mathrm{g}$ i.m. licerelin, a GnRH analogue (Gestran ${ }^{\circledR}$, Tecnopec, SP, Brazil).

Ten animals per group were subjected to real-time ultrasound (Aloka SSD 500 ${ }^{\circledR}$ - Aloka Co., Tokio, Japan) equipped with $5.0 \mathrm{MHz}$ linear transducer, adapted with a plastic support to be manipulated externally in the rectum. Exams were performed at 12, 24, 36, 48 and 60 hours after sponge removal, by the same operator. The number, relative position and size of all follicles with a diameter of $3 \mathrm{~mm}$ were mapped. The timing of ovulation, total numbers of follicles ovulating and mean diameter of the largest and second largest follicle were recorded. The day of ovulation was defined as the day when the largest follicle was no longer seen.

Blood samples were collected by jugular venipuncture using EDTA venous blood vacuum collection tubes (Becton \& Dickinson Vacutainer ${ }^{\circledR}$ Systems, Americana, São Paulo) at the time of sponge insertion (D0), on the fourth day of progestagen treatment (D4), at eCG and d-cloprostenol administration (D5), at sponge removal (D6) and one day later(D7). Samples were immediately placed and maintained on ice until centrifugation at $1000 \mathrm{Xg}$ for $15 \mathrm{~min}$. Plasma was stored in duplicate at $-20{ }^{\circ} \mathrm{C}$ until hormone analyses. Progesterone $(\mathrm{ng} / \mathrm{mL})$ was determined by the direct solidphase radioimmunoassay kits (RIA; Coat-a-Count ${ }^{\circledR}$, Diagnostic Products Corporation, Los Angeles, CA). The mean intra- and inter-assay coefficient of variation were $8.8 \%$ and $9.7 \%$, respectively. Animals were assigned again to be laparoscopic intrauterine inseminated $(n=25)$ or naturally mated $(n=41)$. All the ewes were exposed in groups of five animals for 30 min every 12 hours from 12 to $60 \mathrm{~h}$ following the sponge withdrawal with the aid of the rams, when estrous was detected and recorded. The onset of oestrus was confirmed by the passive ability of the ewes to stimulate the interest of the ram, and was usually quantified by measuring his behavior. The end of oestrus was determined by the refusal of immobility in front of the ram by ewe.

Semen from rams was collected with artificial vagina. Each ejaculate was immediately evaluated to determine the motility of the semen. All the ejaculates with motility higher than $70 \%$ were diluted in a Tris-Frutose extender (Evans, Maxwell, 1987) to contain 100x 106 viable sperm per $0.25 \mathrm{~mL}$ straw. The diluted semen was kept at $37{ }^{\circ} \mathrm{C}$ in a water bath until insemination and semen motility was assessed no more than 30 minutes prior to insemination. Each ewe was intrauterine-inseminated at 48 hours after SW with a single dose of fresh semen. Half the semen dose was deposited within each uterine horn by laparoscopy. Ewes were further evaluated for pregnancy status 45 days after artificial insemination/mating by real-time ultrasonography.

The variables recorded were: interval from sponge removal to artificial insemination (hours); ovulation rate (\%): (number of animals that ovulated/number of ultrasound evaluated animals $) \times 100$; number of ovulations: average number of ovulations per ewe; follicle diameter $(\mathrm{mm})$; percentage of animals in estrus (\%): (number of females in estrus/number of females treated) $\times 100$; pregnancy rate (\%): (number of pregnant females/number of females exposed) $\times 100$; interval from sponge removal to ovulation (h); interval to estrus: interval (h) from sponge removal to time of first estrous identification (onset of estrus); duration 
of estrus: interval (h) from the time of the first to the last estrous identification for each animal. The intervals were calculated considering the difference of time between the first and the last identification.

Statistical analysis was performed for a $95 \%$ confidence interval. Non-parametric variables expressed in percentage (\%) were compared between treatments by using the ChiSquare Test $\left(\chi^{2}\right)$. Parametric variables were expressed as mean \pm standart deviation and submitted to one-way analysis of variance and compared by the Tukey Test using the software SAEG (System for Statistical Analysis, version 8.1).

\section{Results and Discussion}

The administration of $25 \mu \mathrm{g}$ GnRH $24 \mathrm{~h}$ after sponge removal had no significant effect on fertility or time of estrus. Ovulation rate, follicular diameter and average interval to ovulation did not differ $(\mathrm{P}>0.05)$ between treatment groups (Table 1).

The total ovulation rate of $95 \%(19 / 21)$ indicates the efficiency of the protocol employed. The number of ovulations per ewe, the average follicular diameter and interval to ovulation did not differ between groups and were similar to other studies (Pinna et al., 2012). Other studies with short progestagen protocols showed similar efficiency. Reyna et al. (2007) confirmed ovulation in 100\% of Merino ewes during the breeding season using sponges impregnated with $30 \mathrm{mg}$ Flugestone Acetate for 12 days plus an intramuscular injection of $400 \mathrm{IU}$ pregnant mare serumgonadotrophin (PMSG) at SW and $40 \mu \mathrm{g}$ of a synthetic $\mathrm{GnRH}$ given at $36 \mathrm{~h}$ after SW. From the standpoint of mean follicle size $(6.09 \pm 1.16 v s 6.09 \pm 1.16 \mathrm{~mm})$ and synchronization of ovulation (3.8 vs 4.4 days) these authors did not observe difference between GnRH-treated or non-treated groups. Luther et al. (2007) also tested GnRH in Hampshire and Montadale ewes during the breeding season. All ewes were implanted with norgestomet plus $400 \mathrm{IU}$ eCG and $25 \mu \mathrm{g}$ GnRH 36 h after progestin removal. The GnRH treatment did not affect the efficiency of estrous synchronization (progestin with $\mathrm{GnRH}, 85.1 \%$ versus progestin without GnRH, 90.3\%) and pregnancy rates after laparoscopic artificial insemination (progestin with GnRH, 53.7\% versus progestin without GnRH, 61.3\%). However, Takada et al. (2012) reported $58.0 \%$ of Suffolk ewes ovulating, using $60 \mathrm{mg}$ MAP-impregnated sponges for 4 days associated to estradiol benzoate, d-cloprostenol and $50 \mu \mathrm{g} \mathrm{GnRH}$ (gonadorelin) 48 hours after sponge removal.

In regard to number of ovulation per ewe, our results are similar to those presented for other protocols. Takada et al. (2012) reported 1.17 \pm 0.17 in Suffolk ewes using $60 \mathrm{mg}$ MAP-impregnated sponges for 4 days associated to estradiol benzoate, d-cloprostenol and $50 \mu \mathrm{g}$ of $\mathrm{GnRH}$ (gonadorelin) $48 \mathrm{~h}$ after sponge removal. However, Knights et al. (2001) induced estrous of 275 ewes (Suffolk and Dorset predominance) with controlled internal drug release device (CIDR) for 5 days in combination with follicle-stimulating hormone (FSH) and observed an average of $1.95 \pm 0.1$ ovulations per ewe by transrectal ultrasonography.

In accordance with the present results, Bartlewski et al. (1999) and Evans et al. (2000) reported the maximum follicular diameter in ewes as $5-7 \mathrm{~mm}$. The former examined Western White-faced and Finnish Landrace ewes daily by transrectal ultrasonography during one estrous cycle in the middle of the breeding season and the latter used Texel and SuffolkCross ewes by transrectal ultrasonography and follicle dissection after synchronization using a progestagenreleasing intravaginal device.

The interval to ovulation in both control $(59 \mathrm{~h})$ and GnRH ewes ( $58 \mathrm{~h}$ ) was shorter than in other studies that did not use GnRH and assessed each ovary using a transrectal ultrasonographic procedure (Cardwel et al., 1998; Cline et al., 2001). Interestingly Martemucci \& D’Alessandro (2011) conducted experiments in dry ewes with different protocols using GnRH. As a result, they observed an earlier ovulation time $(53.0 \mathrm{~h})$ in ewes treated with FGA during 5 days, plus PGF $(2 \alpha)$ on day 5 and GnRH 30 h after SW than in ewes that received an extra dose of eCG on day $5(61.6 \mathrm{~h})$. In the present trial, induction of early peak of LH and faster response from the largest follicle enhancing follicular steroidogenesis and induction of ovulation were expected. In cattle, exogenous progesterone-progestagen treatments combined with the use of exogenous oestradiol or GnRH

Table 1 - Ultrasonography parameters (mean \pm standart deviation) of ewes treated with MAP sponges for 6 days with ( $\mathrm{T}_{\mathrm{GnRH}}$ ) or without $\left(\mathrm{T}_{\text {Control }}\right)$ administration of GnRH 24 hours after sponge removal and subjected to artificial insemination or natural mating

\begin{tabular}{lccc}
\hline & $\mathrm{T}_{\text {Control }}(\mathrm{n})$ & $\mathrm{T}_{\mathrm{GnRH}}(\mathrm{n})$ & $\mathrm{T}$ \\
\hline Ovulation rate $(\%)$ & $100.0(10 / 10)$ & $90.0(9 / 10)$ & $95.0(19 / 20)$ \\
Number of ovulations & $1.1 \pm 0.3(9)$ & $1.2 \pm 0.4(9)$ & $1.2 \pm 0.4(18)$ \\
Follicular diameter $(\mathrm{mm})$ & $6.4 \pm 0.7(9)$ & $6.2 \pm 0.6(9)$ & $6.3 \pm 0.6(18)$ \\
IOV (hours) & $59.1 \pm 3.5(9)$ & $58.4 \pm 3.5(9)$ & $58.7 \pm 3.4(18)$ \\
\hline
\end{tabular}

No differences detected between treatments ( $P>0.05$; Tukey test).

IOV - interval from sponge removal to ovulation; SD - stardard deviation.

R. Bras. Zootec., v.41, n.6, p.1412-1418, 2012 
are used to control new follicle wave emergence and to shorten the life span of the corpus luteum (Diskin et al., 2002), improving synchronization of ovulation. Moreover, follicles acquired ovulatory capacity at about $10 \mathrm{~mm}$, corresponding to about 1 day after the start of follicular deviation, but they required a greater LH dose to induce ovulation compared with larger follicles (Sartori et al., 2001). In sheep, there is broad agreement that the ovulatory follicle(s) exerts dominance over other follicles during the follicular phase as seen by a decrease in the numbers and emergence of non-ovulatory follicles; however, other data would suggest that clear dominance does not occur in sheep (Evans et al., 2003a). Given the capacity of subordinate follicle to acquire ovulatory capacity, one can infer that the GnRH and subsequent LH surge could stimulate ovulation. However, only three of nineteen animals had double ovulation (data not shown). Ovulatory response in cattle may involve an increased expression of LH receptors on granulosa cells of the dominant follicle and this change may also be important for further growth of the dominant follicle (Sartori et al., 2001). The ovulatory response to GnRH injection might depend on the time of treatment and size of ovulatory follicle. Further research is worthwhile to measure in vivo ovulatory capacity and the mechanisms involved in follicle growth near the critical time of diameter deviation in ewes.

Progesterone declined progressively to subluteal levels on day 5, one day after cloprostenol administration and remained basal up to day 7 (Figure 1). As observed by plasma progesterone concentration along the treatment, few animals (4/20) presented less than $1 \mathrm{ng} / \mathrm{mL}$ in all measurements and were considered non-cyclic. All other animals had higher dosages at some point. According to Sasa et al. (2002) and Traldi (2000), the cyclic activity of Santa Inês ewes in this region of the country does not cease during the year. Considering this, animals were considered as cycling.

Estrous response, interval to estrus and duration of estrus were similar $(\mathrm{P}>0.05)$ for $\mathrm{T}_{\mathrm{Control}}$ and $\mathrm{T}_{\mathrm{GnRH}}($ Table 2$)$.

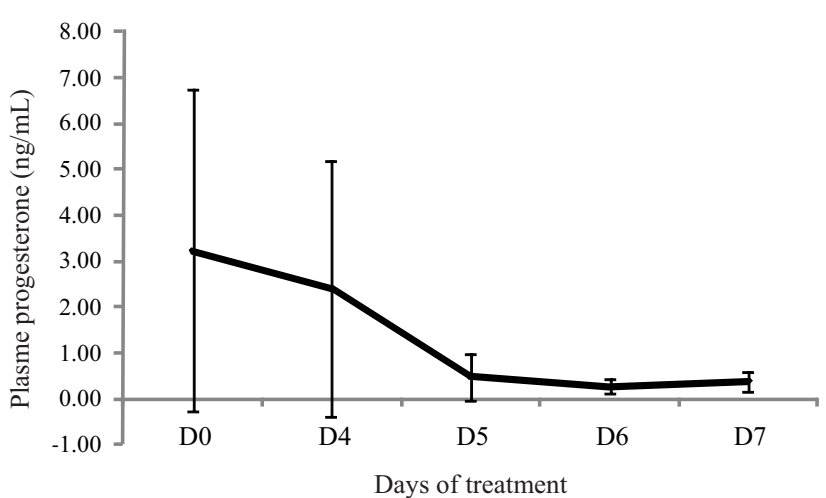

Figure 1 - Plasma progesterone concentration $(\mathrm{ng} / \mathrm{mL})$ in estroussynchronized ewes receiving $60 \mathrm{mg}$ MAP sponges for six days plus $300 \mathrm{IU}$ eCG and $30 \mu \mathrm{g}$ d-cloprostenol 24 hours before sponge removal.

Interval to estrus varied from 22.5 to 32.5 hours, except for one Santa Inês ewe of $\mathrm{T}_{\text {Control, }}$, which showed estrous at 56.5 hours after $\mathrm{SW}$ and low plasma progesterone $(0.42 \mathrm{ng} / \mathrm{mL})$ on day 0 and two Santa Inês ewes of $\mathrm{T}_{\mathrm{GnRH}}$ that showed estrous earlier, at $8.5 \mathrm{~h}$ after SW. Duration of estrous ranged from 12 to 40 hours. Although the expected is from 24 to 30 hours (Robertson, 1977), estrous synchronization protocol resulted in great synchrony of estrus, since $70.7 \%(29 / 41)$ of the animals were in estrus at 24 hours (Figure 2) after sponge removal, except for one ewe treated with GnRH which did not display signs of behavioral estrus $(2.4 \%-1 / 41)$.

The average interval to estrus in the present study (31.4 \pm 7.3 hours) indicates a highly acceptable estrous synchrony of animals. Previous studies (Boscos et al., 2002; Luther et al., 2007) reported similar interval to estrous using short (6 days) or long (14 days) progestagen protocols, with or without GnRH. The interval to estrus $(29.85 \pm 6.98 \mathrm{~h}$ for $\mathrm{T}_{\mathrm{GnRH}}$ and $32.9 \pm 7.5 \mathrm{~h}$ for $\mathrm{T}_{\text {Control }}$ ) was shorter than those reported previously (Pierson et al., 2003). However, maximum and minimum values, 13.5 and $65.1 \mathrm{~h}$, respectively, were similar to others studies (Husein \& Kridli, 1998;

Table 2 - Interval to estrous (h) and duration of estrous (hours; mean \pm standart deviation) of ewes treated with MAP sponges for 6 days with $\left(\mathrm{T}_{\mathrm{GnRH}}\right)$ or without $\left(\mathrm{T}_{\mathrm{Control}}\right)$ administration of GnRH 24 hours after sponge removal

\begin{tabular}{lccr}
\hline & $\mathrm{T}_{\text {Control }}(\mathrm{n})$ & $\mathrm{T}_{\mathrm{GnRH}}(\mathrm{n})$ & $\mathrm{T}$ \\
\hline Interval to estrus (hours) & & & $\mathrm{n})$ \\
Santa Inês/Dorper crossbred & $29.5 \pm 0.4(6)$ & $29.5 \pm 0.4(7)$ & $29.5 \pm 0.0(13)$ \\
Santa Inês & $34.4 \pm 8.6(14)$ & $30.0 \pm 8.8(13)$ & $32.3 \pm 8.8(27)$ \\
Total & $32.9 \pm 7.0(20)$ & $29.8 \pm 7.0(20)$ & $31.4 \pm 7.3(40)$ \\
Estrous duration (hours) & & & \\
Santa Inês/Dorper crossbred & $36.0 \pm 7.6(6)$ & $34.3 \pm 4.5(7)$ & $35.1 \pm 5.9(13)$ \\
Santa Inês & $38.1 \pm 9.7(14)$ & $30.1 \pm 12.5(13)$ & $34.2 \pm 11.7(27)$ \\
Total & $37.4 \pm 9.0(20)$ & $31.5 \pm 10.4(20)$ & $34.5 \pm 10.1(40)$ \\
\hline
\end{tabular}

No differences between treatments ( $>0.05$; Tukey Test); SD - standard deviation. 
Barret et al., 2004). In cyclic ewes, eCG given after progestagen treatment reduces the interval to onset of estrus, when compared with ewes given only progestagen (Husein \& Kridli, 1998; Dias et al., 2000). Gonadotropin enhances estrogen concentration and induces estrous and LH surge.

As expected, GnRH did not influence estrous duration (ED), once eCG is more important in determining estrous duration because it stimulates follicle development enhancing the recruitment of small follicles (Evans et al., 2003). The mean estrous duration for all animals ( $34.5 \pm 10.1$ hours) is compatible with physiological reports. According to Mobini et al. (2002) estrous could vary between 15 and 45 hours, with an average of 30 hours. A classical report by Robertson (1977) considered that behavioral estrus in ewe normally lasts $24-30$ hours. Besides that, the findings agree with results of Ekiz et al. (2009), who reported a longer estrous duration (34.80 \pm 2.15 hours) when estrous was synchronized with fluorgestone acetate intravaginal sponges left for 14 days, plus an injection of 600 IU PMSG at the time of sponge removal and ewes were exposed to ram twice a day than when remaining with the ram permanently (15.60 \pm 1.83 hours). Turk et al. (2008) reported $29.9 \mathrm{~h}$ after progestagen, PMSG and prostaglandin treatment.

Estrous was recorded during mating. Most animals $70.7 \%(29 / 41)$ showed estrus within $24 \mathrm{~h}$ after SW (Figure 2). Regardless of the GnRH treatment, when short-term progestagen protocol is used, there is a little dispersion of estrus.

The interval from sponge removal to artificial insemination was similar $(\mathrm{P}>0.05)$ for $\mathrm{T}_{\text {Control }}(53.7 \pm 0.9$ hours) and $\mathrm{T}_{\mathrm{GnRH}}(53.6 \pm 1.3$ hours $)$, at around $6 \mathrm{~h}$ before ovulation detection. The minimum and maximum values recorded were 51.7 and 56.5 hours. The resultant conception rates were similar between treatment and mating groups (Table 3).

In spite of a greater conception rate for $\mathrm{T}_{\text {Control }}$, there was no statistical difference between treatment groups (57.0\% for $\mathrm{T}_{\text {Control }}$ and $41.0 \%$ for $\mathrm{T}_{\mathrm{GnRH}}$ ). Reyna et al. (2007) showed that GnRH injection 36 hours after sponge removal improved ovulation synchronization, despite having no effect on conception rates using laparoscopic artificial insemination at 42 hours $(20.20 \%)$ or 48 hours $(19.26 \%)$ after progestegen treatment.

Conception rates by natural mating $(55.00 \%)$ were similar in others studies (Viñoles et al., 2001; Dixon et al., 2006). However, results differed from studies with long and short progestagen protocols and variable dosages of eCG (Ungerfeld, Rubianes, 1999; Shahneh et al., 2006), which reported conception rates superior to $70 \%$.

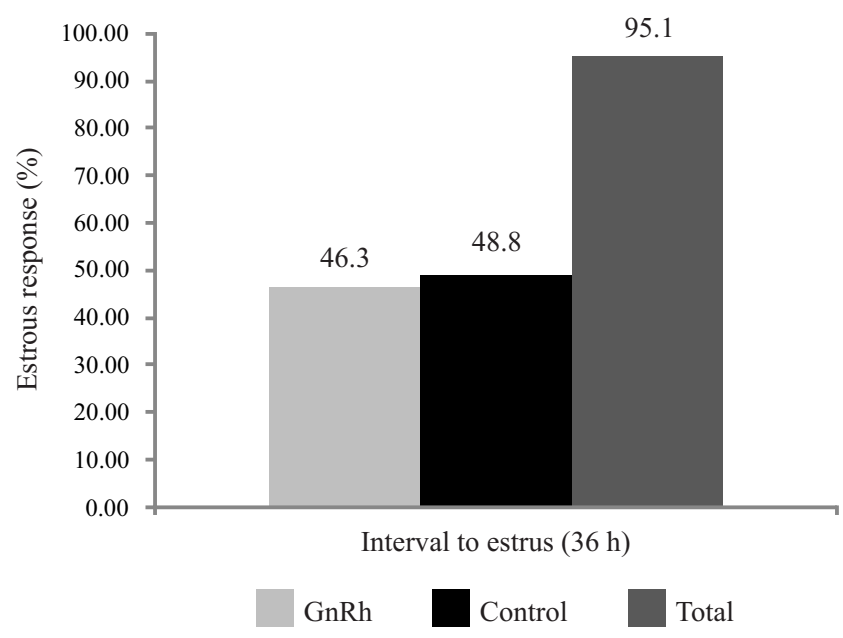

Figure 2 - Interval to estrous response in ewes receiving $60 \mathrm{mg}$ MAP sponges for six days plus $300 \mathrm{IU}$ eCG, $30 \mu \mathrm{g}$ d-cloprostenol 24 hours before and with or without GnRH 24 hours after sponge removal.

Nevertheless, the low conception rate observed when laparoscopic artificial insemination was used (37.5\%) with fresh semen was an unexpected finding, since rates of 55.9\% (Luther et al., 2007) and 53.3\% (Lucidi et al., 2001) were reported. Contreras-Solis et al. (2009), using 12-day FGA treatment and artificial insemination at $55 \mathrm{~h}$ after SW showed $47.4 \%$ of fertility rate. In a Brazilian study, Dias et al. (2001) carried out an experiment on artificial insemination of hairy ewes. In their experiment, females were synchronized with sponges impregnated with $30 \mathrm{mg}$ fluorogestone acetate and $200 \mathrm{IU}$ eCG were given at the end of treatment. After laparoscopic artificial insemination with frozen semen, they achieved a $33.3 \%$ pregnancy rate.

Average interval to artificial insemination $(53.6 \pm 1.1 \mathrm{~h})$ was very close to ovulation $(58.7 \pm 3.4 \mathrm{~h})$ and fresh semen needs some interval in the female reproductive tract for sperm capacitation (Cohen et al., 2004; Breitbart et al., 2005). Therefore, when spermatozoa were able to fertilize, the oocyte was old, resulting in low fertility. Artificial insemination using fresh semen was recommended to be

Table 3 - Conception rate in ewes treated with MAP for 6 days with $\left(\mathrm{T}_{\mathrm{GnRH}}\right)$ or without $\left(\mathrm{T}_{\text {Control }}\right) \mathrm{GnRH} 24 \mathrm{~h}$ after sponge removal and subjected to laparoscopic artificial insemination (LAI) or natural mating (NM)

\begin{tabular}{lccc}
\hline & $\mathrm{T}_{\text {Control }}(\mathrm{n})$ & $\mathrm{T}_{\text {GnRH }}(\mathrm{n})$ & Total $(\mathrm{n})$ \\
\hline $\mathrm{NM}$ & $65.0 \%(13 / 20)$ & $45.0 \%(9 / 20)$ & $55.0 \%(22 / 40)$ \\
LAI & $40.0 \%(4 / 10)$ & $35.7 \%(5 / 14)$ & $37.5 \%(9 / 24)$ \\
Total & $57.0 \%(17 / 30)$ & $41.0 \%(14 / 34)$ & $48.0 \%(31 / 64)$ \\
\hline
\end{tabular}

No differences detected between treatments $(\mathrm{P}>0.05 ;$ Chi-Square Test). 
done $48 \mathrm{~h}$ after sponge removal and using frozen semen this interval is $58 \mathrm{~h}$ after sponge removal (Maxwell, 1986) This interval corresponds to the interval to ovulation in the present study $(58.7 \pm 3.4 \mathrm{~h})$. These data suggested that when GnRH is used, fixed time artificial insemination with fresh semen should be done earlier. Gillan et al. (1997) showed that $54 \%$ of freshly collected spermatozoa become capacitated with incubation $\left(6 \mathrm{~h}\right.$ at $\left.37^{\circ} \mathrm{C}\right)$. In contrast, frozen spermatozoa displayed a $65.9 \%$ capacitation rate. This demonstrates that cryopreservation may cause membrane changes in ram spermatozoa functionally equivalent to capacitation. This way, the interval to artificial insemination (53.6 1 1.1 hours) used in the present study should be more appropriate for frozen semen. Success of fertilization depends on artificial insemination or ovulation time and control of these factors could improve conception rate.

\section{Conclusions}

Six-day progesterone priming, in combination with $\mathrm{GnRH}, \mathrm{PGF}_{2} \alpha$ and eCG can be used sucessfully for ovulation and estrous induction/synchronization in Santa Inês and Santa Inês/Dorper crossbred ewes, but there is no effect on pregnancy rate in Santa Inês/Dorper crossbred ewes during the breeding season.

\section{Acknowledgements}

The preparation of this paper was supported by funds from Universidade Federal Fluminense and Embrapa Caprinos e Ovinos. In addition, fellowship was provided from $\mathrm{CNPq}$ to A.S. Cavalcanti. We thank Dr. Walter Lilenbaum for critical reading of an earlier version of this paper; Tecnopec, for hormonal supplies; and Elíseo Balbino, for allowing us to conduct the experiment on his farm.

\section{References}

AMARANTIDIS, I.; KARAGIANNIDIS, A.; SARATSIS, P.H. et al. Efficiency of methods for estrous synchronization in indigenous Greek goats Small Ruminant Research, v.52, p.247-252, 2004.

BAKKER, J.; BAUM, M.J. Neuroendocrine regulation of GnRH release in induced ovulators. Frontiers of Neuroendocrinology v.21, p.220-262, 2000.

BARRET, D.M.W.; BARTLEWISKI, P.M.; COOK, S.J. et al. Ultrassound and endocrine evaluation of the ovarian response to PGF $2 \alpha$ given at different stages of the luteal phase in ewes. Theriogenology, v.58, p.1409-1424, 2002 .

BARRET, D.M.W.; BARTLEWSKI, P.M.; BATISTA-ARTEAGA, M. et al. Ultrasound and endocrine evaluation of the ovarian response to a single dose of $500 \mathrm{IU}$ of the eCG following a 12 -day treatment with progestogen-releasing intravaginal sponges in the breeding and nonbreeding seasons in ewes. Theriogenology, v.61, 311-327, 2004.

BARTLEWSKI, P.M.; BEARD, A.P.; COOK, S.J. et al. Ovarian antral follicular dynamics and their relationships with endocrine variables throughout the oestrous cycle in breeds of sheep differing in prolificacy. Journal of Reproduction and. Fertility, v.115, p.111-124, 1999.

BEILBY, K.H.; GRUPEN, C.G.; THOMSON, P.C. et al. pregnancy rate using sex-sorted ram sperm The effect of insemination time and sperm dose on pregnancy rate using sex-sorted ram sperm. Theriogenology v.71, p.829-835, 2009.

BOSCOS, C.M.; SAMARTZI, F.C.; DELLIS, S. et al. Use of progestagen-gonadotropin treatments in estrus synchronization of sheep. Theriogenology, v.58, p.1261-1272, 2002.

BREITBART, H.; COHEN, G.; RUBINSTEIN, S. Role of actin cytoskeleton in mammalian sperm capacitation and the acrosome reaction. Reproduction, v.129, p.263-268, 2005.

CARDWEL, B.E.; FITCH, G.Q.; GEISERT, R.D. Ultrasonic evaluation for the time of ovulation in ewes treated with norgestomet and norgestomet followed by pregnant mare's serum gonadotropin. Journal of Animal Science, v.76, p.2235-2238, 1998.

CLINE, M.A.; RALSTON, J.N.; SEALS, R.C. et al. Intervals from norgestomet withdrawal and injection of equine chorionic gonadotropin or P.G. 600 to estrus and ovulation in ewes. Journal of Animal Science, v.79, p.589-594, 2001.

COELHO, L.A.; RODRIGUES, P.A.; NONAKA, K.O. et al. Annual pattern of plasma melatonin and progesterona concentrations in hair and wool ewe lambs kept under natural photoperiod at lower latitudes in the southern hemisphere. Journal of Pineal Research, v.41, p.101-107, 2006

COHEN, G.; RUBINSTEIN, S.; GUR, Y. et al. Crosstalk between protein kinase $\mathrm{A}$ and $\mathrm{C}$ regulates phospholipase $\mathrm{D}$ and $\mathrm{F}$-actin formation during sperm capacitation Development of Biology, v.267, p.230-241, 2004.

CONTRERAS-SOLIS, I.; VASQUEZ, B.; DIAZ, T. et al. Efficiency of estrous synchronization in tropical sheep by combining shortinterval cloprostenol-based protocols and "male effect" Theriogenology, v.71, n.6, p.1018-1025, 2009.

DIAS, E.F.; LOPES JÚNIOR, E.S.; VILLAROEL, A.B.S. et al. Sincronização do estro, indução da ovulação e fertilidade de ovelhas deslanadas após tratamento hormonal com gonadotrofina coriônica eqüina. Arquivo Brasileiro de Medicina Veterinária e Zootecnia, v.53, n.5, p.618-623, 2001.

DISKIN, M.G.; AUSTIN, E.J.; ROCHE, J.F. Exogen hormonal manipulation of variance activity in cattle. Domestic Animal Endocrinology, v.23, p.211-228, 2002.

DIXON, A.B.; KNIGHTS, M.; PATE, J.L. et al. Reproductive performance of ewes after 5-day treatment with intravaginal inserts containing progesterone in combination with injection of prostaglandin $\mathrm{F}_{2} \alpha$. Reproduction in Domestic Animals, v. 41, p. $142-148,2006$.

DELIGIANNIS, C.; VALASI, I.; REKKAS, C.A. et al. Synchronization of ovulation and fixed time intrauterine insemination in ewes. Reproduction in omestic Animals, v.40, n.1, p.6-10, 2005.

DONOVAN, A.; HANRAHAN, J.P.; KUMMEN, E. et al. Fertility in the ewe following cervical insemination with fresh or frozenthawed semen at a natural or synchronised oestrus Animal Reproduction Science, v.84, p.359-368, 2004.

EPPLESTON, J.; EVANS, G.; ROBERTS, E.M. Effect of time of PMSG and GnRH on the time of ovulation, LH secretion and reproductive performance after intrauterine insemination with frozen ram semen Animal Reproduction Science, v.26, n.3-4, p.227-237, 1991.

EVANS, A.C.O.; MAXWELL, W.M.C. Salomon's artificial insemination of sheep and goats. Sydney: Butterworths, 1987. $194 \mathrm{p}$.

EVANS, A.C.O.; DUFFY, P.; HYNES, N. et al. Waves of follicle development during the estrous cycle in sheep. Theriogenology, v.53, p.699-715, 2000. 
EVANS, A.C.O. Characteristics of ovarian follicle development in domestic animals. Reproduction in Domestic Animals, v.38, n.4, p.240-246, 2003.

FONSECA, J.F.; TORRES, C.A.A.; SANTOS, A.D.F. et al. Progesterone and behavioral features when estrous is induced in Alpine goats. Animal Reproduction Science, v.103, p.366-373, 2008 .

GILLAN, L.; EVANS, G.; MAXWELL, W.M. Capacitation status and fertility of fresh and frozen-thawed ram spermatozoa. Reproduction and Fertility and Development, v.9, p.481-487, 1997

GORDON, I. Controlled reproduction in sheep and goats. Cambridge: University Press, 1997. 450p.

HILL, J.R.; THOMPSON, J.A.; PERKINS, N.R. Factors affecting pregnancy rates following laparoscopic insemination of 28,447 Merino ewes under commercial conditions: a survey. Theriogenology, v.49, n.4, p.697-709, 1998.

HUSEIN, M.Q.; BAILEY, M.T.; ABABNEH, M.M. et al. Effect of eCG on the pregnancy rate of ewes transcervically inseminated with frozen-thawed semen outside the breeding season. Theriogenology, v.49, p.997-1005, 1998.

HUSEIN, M.Q; KRIDLI, R.T. Effect of progesterone prior to GnRH-PGF $2 \alpha$ treatment on induction of oestrus and pregnancy in anoestrous Awassi ewes. Reproduction in Domestic Animals, v.38, p.228-232, 2003.

IIDA, K.; KOBAYASHI, N.; KOHNO, H. et al. comparative study of induction of estrus and ovulation by three different intravaginal devices in ewes during the non-breeding season Journal of Reproduction and Development, v.50, p.63-69, 2004.

JOHNSON, S.K.; DAILEY, R.A.; INSKEEP, E.K. et al. Effect of peripheral concentrations of progesterone on follicular growth and fertility in ewes. Domestic Animal Endocrinology, v.13, n.1, p.69-79, 1996.

KLEEMANN, D.O.; WALKER, S.K. Fertility in South Australian commercial Merino flocks: sources of reproductive wastage. Theriogenology, v.63, p.2075-2088, 2005.

KNIGHTS, M.; HOEHN, T.; LEWIS, P.E. et al. Effectiveness of intravaginal progesterone inserts and $\mathrm{FSH}$ for inducing synchronized estrus and increasing lambing rate in anestrous ewes. Journal of Animal Science, v.79, p.1120-1131, 2001.

LUCIDI, P.; BARBONI, B.; MATTIOLI, M. Ram-induced ovulation to improve artificial insemination efficiency with frozen semen in sheep. Theriogenology, v.55, p.1797-1805, 2001.

LUTHER, J.S.; GRAZUL-BILSKA, A.T.; KIRSCH, J.D. et al. The effect of GnRH, eCG and progestin type on estrous synchronization following laparoscopic AI in ewes. Small Ruminant Research, v.72, p.227-231, 2007.

MARTEMUCCI, G.; D'ALESSANDRO, A.G. Synchronization of oestrus and ovulation by short time combined FGA, PGF $2 \alpha$, $\mathrm{GnRH}$, eCG treatments for natural service or AI fixed-time Animal Reproduction Science, v.123, p.32-39, 2011.

MAXWELL, W.M.C. Artificial insemination of ewes with frozenthawed semen at a synchronised oestrus. 1. Effect of time of onset of oestrus, ovulation and insemination on fertility. Animal Reproduction Science, v.10, p301-308, 1986.

MOBINI, S.; HEATH, A.M.; PUGH, D.G. Theriogenology of sheep and goats. In: PUGH, D.G. (Ed). Sheep and goat medicine. Pennsylvania: W.B. Saunders, 2002. p.129-196.

MURDOCH, W.J.; VAN KIRK, E.A. Luteal dysfunction in ewes induced to ovulate early in follicular phase. Endocrinology, v.139, p.3480-3484, 1998.
PIERSON, J.T.; BALDASSARRE, H.; KEEFER, C.L. et al Influence of GnRH administration on timing of the LH surge and ovulation in dwarf goats. Theriogenology, v.60, p.397-406, 2003.

PINNA, A.E.; BRANDÃO, F.Z.; CAVAlCANTI, A.S. et al. Reproductive parameters of Santa Inês ewes submitted to shortterm treatment with re-used progesterone devices. Arquivo Brasileiro de Medicina Veterinária e Zootecnia, v.64, n.2, p.333-340, 2012.

REYNA, J.; THOMSON, P.C.; EVANS, G. et al. Synchrony of ovulation and follicular dynamics in Merino ewes treated with GnRH in the breeding and non-breeding seasons. Reproduction of Domestic Animals, v.42, p.410-417, 2007.

RIBEIRO JÚNIOR, I. Análises estatísticas no SAEG. Viçosa, MG: UFV, 2001. 301p.

ROBERTS, A.J.; DUNN, T.G.; MURDOCH, W.J. Induction of ovulation in proestrous ewes: identification of the ovulatory follicle and functional status of the corpus luteum. Domestic Animals Endocrinology, v.2, p.207-210, 1985.

ROBERTSON, H.A. Reproduction in the ewe and the goat. In: COLE, H.H.; CUPPS, P.T. (Eds.) Reproduction in domestic animals. New York: Academic Press, 1977. p.475-498.

RUBIANES, E.; BEARD, A.; DIERSCHKE, D.J. et al. Endocrine and ultrasound evaluation of the response to $\mathrm{PGF}_{2} \alpha$ and $\mathrm{GnRH}$ given at different stages of the luteal phase in cyclic ewes. Theriogenology, v.48, p.1093-1104, 1997.

SARTORI, R.; FRICKE, P.M.; FERREIRA, J.C.P. et al. Follicular deviation and acquisition of ovulatory capacity in bovine follicles Biology of Reproduction, v.65, p.1403-1409, 2001.

SASA, A.; TESTON, D.C.; RODRIGUES, P.A. et al. Plasma concentrations of progesterone in hair and wool ewe lambs from April to November, in São Paulo State. Revista Brasileira de Zootecnia, v.31, p.1150-1156, 2002.

SHAHNEH, A.Z.; TAJANGOOKEH, H.D.; PANAH, H.S. et al. Effect of controlled internal drug release device treatment duration and eCG dose on reproductive performance of seasonally anestrous fat-tailed Iranian ewes. Pakistan Journal of Biology Sciences, v.9, n.8, p.1552-1555, 2005.

TAKADA, L.; BICUDO, S.D.; RODRIGUES, C.F.C. et al. Ovarian response of Suffok ewes to estrous synchronization using short-term protocol. Revista Brasileira de Zootecnia, v.41, p.314-319, 2012

TRALDI, A.S. Controle farmacológico do ciclo estral e da superovulação em caprinos e ovinos. In: BARUSELLI, P.; MADUREIRA, H. (Orgs.). Controle farmacológico do ciclo estral em ruminantes. São Paulo: Faculdade de Medicina Veterinária e Zootecnia da Universidade de São Paulo, 2000. p.306-332.

TURK, G.; GUR, S.; SONMEZ, M. et al. Efect of exogenous GnRH at the time of artificial insemination on reproductive performance of Awassi ewes synchronized with progestagen-PMSG-PGF2 $\alpha$ combination. Reproduction in Domestic Animals, v.43, p.308-313, 2008.

UNGERFELD, R.; RUBIANES, E. Effectiveness of short-term progestogen primings for the induction of fertile oestrus with eCG in ewes during late seasonal anoestrus. Animal Science, v.68, p.349-353, 1999

VIÑOLES, C.; FORSBERG, M.; BANCHERO, G. et al. Effect of long-term and short-term progestagen treatment on follicular development and pregnancy rate in cyclic ewes. Theriogenology, v. 55, p.993-1004, 2001.

WILDEUS, S. Current concepts in synchronization of estrus: sheep and goats. Journal of Animal Science, v.77, p.1-14, 2000. 